\section{The fragility of the Palestinian Authority: economic causes}

\section{Basel Saleh}

$\mathrm{T}$ his article examines the evolution of the Palestinian Authority (PA) as a paradigmatic case of state evolution, from stable political regime to fragile, indeed failing, entity. The analysis of the Palestinian political metamorphosis shows how endogenous and exogenous economic shocks led to the current brittle economy and polity in the West Bank and Gaza Strip (WBGS). The article also dispels some myths regarding the collapse of the Palestinian Authority. That collapse was facilitated by multiple exogenous pressures that weakened the core authority of the PA. Notwithstanding self-inflicted problems such as disunity, corruption, and weak governance, the powerful interference by the American-Israeli-Arab coalition has intensified these problems and at times set the stage for their emergence. The issue of state fragility should not be viewed as a native problem but rather as an outcome of powerful historical and contemporary forces that continue to shape the destinies of many nations, including the Palestinian nation, around the world.

The fragile state is losing its ability to provide necessary pubic services such as the enforcement of law and order, enforcing border control, proper management of the economy, and responding to disasters. Also, such a state has limited powers to exert its central authority across its territories. In 2006, the World Bank listed the WBGS as a fragile state for the first time. Among the most visible signs of PA fragility are political fragmentation, corruption, and widespread lawlessness. Fragmentation and lack of cohesion in the WBGS have pitted Palestinians against each other, and this has led, most recently, to Hamas' military takeover of the Gaza strip. ${ }^{1}$ Another indicator of political fragmentation is the splintering of militant groups that now function independent of the official PA security forces. These groups have brought serious problems to the PA, notably through escalating violence that has exacerbated the security situation. ${ }^{2}$

Palestinian corruption has been facilitated by billions of dollars of foreign aid that has gone directly to the PA. ${ }^{3}$ After the signing of the Oslo Accords in 1993, it is estimated that in the period to 2001 , donors provided over $\$ 4$ billion in aid to the Palestinians through the PA. ${ }^{4}$ Corruption within the PA was often tolerated, and sometimes even encouraged, as a means to increase its support base and thus sustain a system of cronyism that characterized the Palestine Liberation Organization, the PA's predecessor. Corruption and financial mismanagement was at times used as a source to finance paramilitary forces that received direct funding from the PA but were never part of any formal law enforcement apparatus in the WBGS. Many of these groups are now posing problems to the recent attempts by the PA to restore law and order and make it difficult to sustain peace efforts with their impromptu attacks on Israelis.

Another aspect of corruption in the PA is the creation of monopolies by leading figures within the PA and the security forces. These have resulted in exorbitant prices on basic goods and low-quality goods and have been used to accumulate personal wealth rather than to provide relief and assistance to Palestinians. ${ }^{5}$ However, since the arrival in 2002 of Salam Fayyad as prime and finance minister, the PA's financial transparency has improved dramatically.

Since the 1993 Oslo Accords, three economic shocks have impaired the performance of the Palestinian economy and have corroded the legitimacy of the PA and contributed to its fragility. They are, first, Israel's chaotic closure policy; second, the structural weaknesses in the Palestinian fiscal budget; and third, certain economic and trade sanctions imposed in 2000 and 2006. However, a central argument of this article is that pre-existing structural weaknesses of the Palestinian economy helped set the stage for the present state of collapse, fragility, and anarchy in the Palestinian territories and for the difficulties any government such as the Palestinian Authority must face. Furthermore, if these underlying issues are not corrected, they will almost inevitably undermine any future peace agreement that Palestinians and Israelis might reach.

\section{Economy under siege}

It is often forgotten that the Palestinian economy first came under the direct control of Israeli authorities after the June 1967 war. From that time on until 1994, Israeli policies toward the Occupied Territories were shaped and driven by three principles: first, the Palestinian economy should complement, not compete, with the Israeli economy; second, political and military considerations should take precedence over economic considerations; and third, the economy of the territories should not add a cost, or otherwise be a burden, to the Israeli economy. ${ }^{6}$ Consequently, the economies of the WBGS remained underdeveloped with investment in machinery and equipment extremely curtailed and access to resources severely limited or even altogether prevented by Israeli authorities. Prior to the Oslo Accords, the Palestinian economy was kept afloat through labor absorption in the Israeli economy (on average 30 percent of Palestinians were working in Israel during 1968-1993), Palestinian labor 
remittances from abroad, and by foreign aid from various countries and international organizations.

The economic development of Palestinians was never an objective under Israeli government control. Even road construction was based on military rather than civilian population needs. Factory permits for Palestinians were often delayed for several years and, when approved, came with strict conditions such as caps on production and other restrictions in the interest of protecting the Israeli economy. ${ }^{7}$ During 27 years of direct Israeli occupation and administration of the Palestinian economy, there was therefore very little investment in infrastructure and other needed components of a healthy economy. From 1967 to 1993, Israel kept a firm grip on Palestinian political and economic affairs. Ironically, while Israeli policy might have served its need for security during the years of occupation, the structural weaknesses it created in Palestinian economic and political life would become a major impediment to peace and stability in the post-Oslo years.

Toward the latter part of the pre-Oslo years, two major political events caused a serious deterioration of Palestinian living conditions in the WBGS and further withered the Palestinian economy: the first Palestinian intifada (1987-1993), and the first Gulf War (1991). The first intifada resulted in reduced work hours, employment opportunities in Israel, and investment activities. ${ }^{8}$ In addition, by the end of the first Gulf W ar Palestinian annual remittances had fallen from $\$ 340$ million to $\$ 120$ million, a 67 percent decline, and unemployment had reached 40 percent. These two events caused Palestinian Gross National Income to fall by 14 percent, a substantial decline. ${ }^{9}$ But these shocks would be but the prelude to more severe shocks that would come during the interim Palestinian self-rule. The difference is that the economic shocks to the Palestinian economy post-Oslo play a large part in the instability of the peace process that ensued.

\section{Prelude to the current crisis}

Given the arrangements that are in place since 1993, any Palestinian government faces a set of unique challenges. The PA is expected to help grow the WBGS economy even as the territory is becoming increasingly fragmented and as the PA lacks needed political, fiscal, and monetary powers. The PA was established in 1994 after Israel and the Palestine Liberation Organization signed a Declaration of Principles (DoP) in Washington, D.C., on 13 September 1993. The DoP resulted from the Oslo peace negotiations that were held in secret between representatives of the PLO and Israel between 1991 and 1992. Essentially an understanding to continue the peace talks until the year 2000, the parties involved were expected to sign a comprehensive peace treaty to establish an independent Palestinian state in the WBGS and officially end the Palestinian-Israeli conflict. But by September 2000, instead of the long-awaited peace agreement coming to fruition, all-out conflict returned with what the media dubbed the al Aqsa or second intifada. That new era of violence erupted soon after the failed
Camp David peace summit in July 2000, sponsored by U.S. President Bill Clinton during his final six months in office.

On 25 January 2006, Palestinian elections were held, for the second time in ten years. ${ }^{10}$ Unlike the first elections which the Palestinian Islamic Resistance Movement (Hamas) boycotted, Hamas decided to take part in the second election. It mobilized and campaigned on a platform of economic and political reforms and managed to win 74 of the 132 seats (56 percent) in the Palestinian Legislative Council. ${ }^{11}$ No landslide victory, it nonetheless astonished the world with its unpredicted outcome. The international community refused to recognize the results of the democratic elections, and the PA's president, Mahmoud Abbas, was pressured into declaring a state of emergency and annulling the election's results, which he refused to do. ${ }^{12}$ But with the backing of the United States, Israel, and some Arab countries, he started a campaign to marginalize the Hamas-led government. Eventually, this led to a brief military confrontation in June 2007 when Hamas fighters took control of the entire Gaza Strip, flushed out PA security forces, and established de facto Islamic rule over the entire Gaza Strip. ${ }^{13}$

\section{Israeli closure policy: distortions to the labor market}

Before 1991, Palestinians, under Israel's general entry permit system, were allowed freedom of movement and travel within the WBGS and into Israel. After 1991, Israel reversed that policy and enforced a permit system whereby Palestinians would have to apply for advance permission to leave the WBGS to enter Israel for any reason. ${ }^{14}$ Naturally, such a system would not be effective without a parallel enforcement strategy. Israel therefore started a system of enforcement measures composed of hundreds of road blocks and checkpoints spread throughout the territories. ${ }^{15}$ Currently, there is one roadblock or checkpoint for every 5 miles of road in the W est Bank, each requiring minutes to hours to pass on the days they are open. Such measures would be expected to carry severe consequences for the Palestinian economy and society. These include Palestinian labor flows that were adversely affected in three directions - from Gaza to Israel; from the West Bank to Israel; and between the West Bank and Gaza - and became erratic, unpredictable, and declined over the years, and in some cases were not permitted at all; the instability of employment in Israel that caused a reduction in consumer incomes and surges in the unemployment rate in the WBGS; and increased transaction costs because of the additional arrangements needed to circumvent the checkpoints. ${ }^{16}$ Figure 1 shows the opposing movements of the percentage of Palestinians working in Israel and the unemployment rate in the Occupied Territories. ${ }^{17}$ Palestinian employment in Israel averaged 14 percent from 1995-2006, while before 1992 the Israeli economy absorbed over 30 percent of the Palestinian labor force, a drop of 114 percent. Naturally, those who were unable to continue to work in Israel had to find local employment in the underdeveloped Palestinian economy that is still subject to Israeli restrictions on trade and investment. 


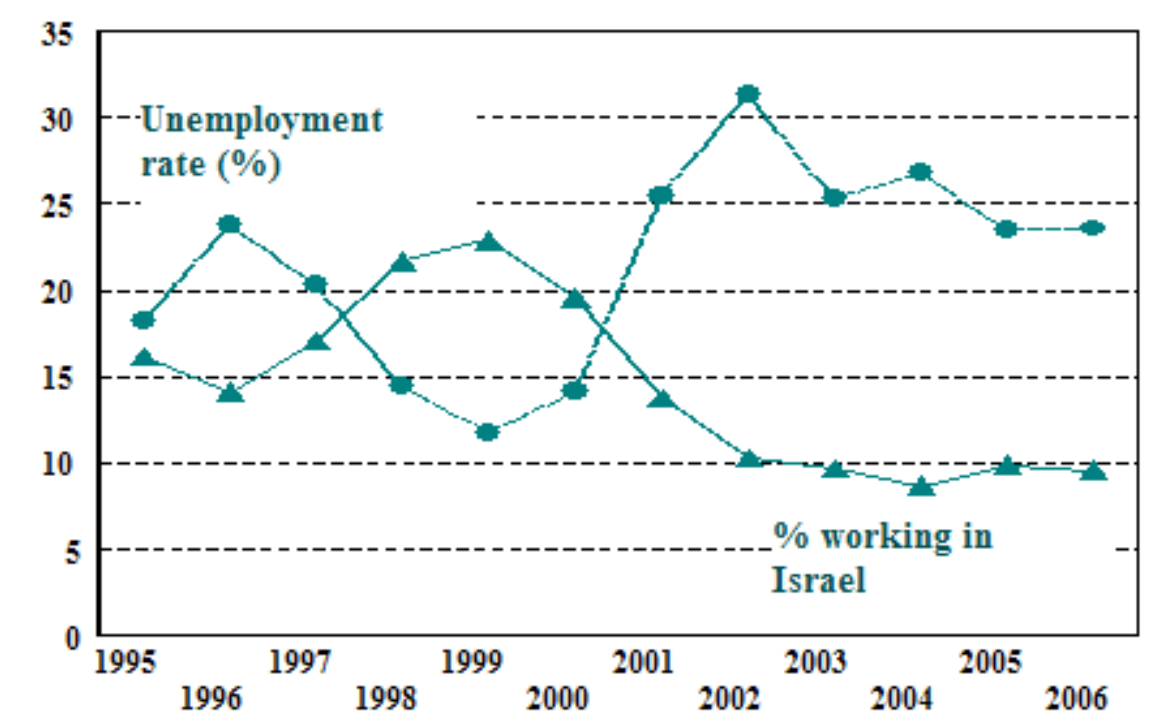

Figure 1: Palestinian unemployment rate vs percentage of Palestinians working in Israel, 1995-2006.

Source: Author's compilation from Palestinian Labor Surveys.

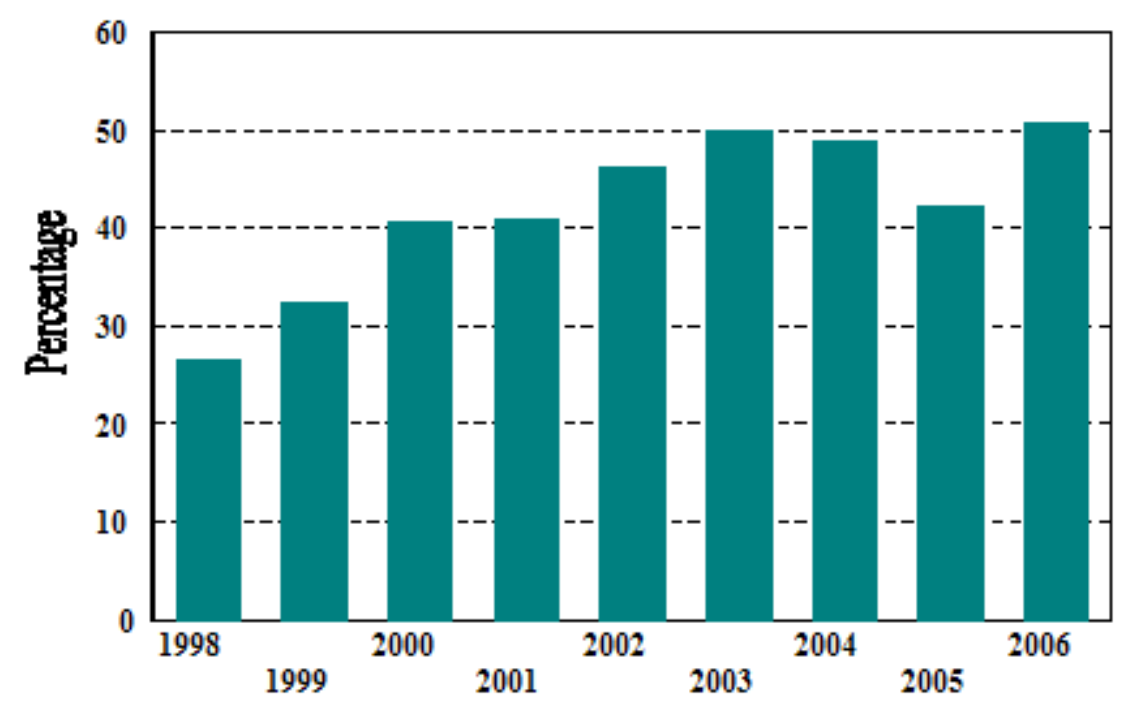

Figure 2: Payroll of a percentage of the PA budget, 1998-2006. Source: Palestinian Ministry of Finance.
Therefore, the arrival of the PA included an attempt to rapidly relieve unemployment in the Palestinian economy (on which more later on).

Fiscal weaknesses: The PA as an alternative to the private economy

Expected to be in charge of the Palestinian economy, the PA's founding structures (the Oslo I and II agreements) endowed it with meager fiscal and monetary powers to be an efficacious public institution. This became evident as the PA started to face fiscal challenges after taking control of Palestinian cities across the WBGS

following Israeli military redeployment that started in 1994. These weaknesses contributed to the debility of the PA and eroded its political legitimacy in the eyes of Palestinians, Israeli, and the international community.

Two major issues are unique to the PA fiscal budget. First, public revenues are dependent upon two sources: Israeli transfer of tax collections, and foreign aid. Palestinian budget data show that more than 50 percent of public spending was financed through foreign support in the form of aid and grants since the inception of the PA. ${ }^{18}$ The other major issue in the PA fiscal budget is the ballooning public expenditure that went primarily for salaries and other recurrent expenses. Between 1998 and 2006, PA payroll spending averaged 42 percent of total expenditure (see Figure 2), over twice the world average. ${ }^{19}$ Salaries and wages increased from Israeli Shekel (IS) 1,746 million ( $\$ 480$ million) to IS 5,695 million ( $\$ 1,265$ million), a 226 percent jump that cannot be explained by inflation alone and might be indicative of utilizing various PA institutions to absorb labor surplus or for the PA to act as an employer of last resort. Between 1994 (the year the PA was established) and 1999, PA employment expanded from 40,000 to 100,000, and by 2007 this number had reached $167,000 .{ }^{20}$ Since 1994 , even as the Palestinian economy stagnated, PA employment continued to expand. The employment increase can be justified on the grounds that, to function as a government, the new PA needed to staff various ministries throughout the WBGS. But the PA has been facing adverse economic conditions from its inception. Israeli closure policy and the sanctions of late 2000 and 2006 have exacerbated the unemployment situation in the territories. As the private sector (especially agriculture and construction) stagnated and employment inside Israel or 
in Israeli settlements has become tenuous and unreliable, more people reverted to employment in the PA. For example, in the Gaza Strip almost 40 percent of the employed are working directly for the PA. Some sources place the number as high as 70 percent. Palestinian Labor Surveys indicate that employment in the public sector expanded from 19.4 percent in 2000 to 23.7 percent in 2006, a 22 percent increase, whereas employment in the private sector for the same period increased only by 9 percent (see Table 1).

Table 2 shows the Palestinian budget from 1998 to 2006. The PA has consistently used deficit financing to run its various operations. That is not unusual when an economy is reeling from extended and negligent occupation and other shocks discussed earlier. But there are some issues of concern for using deficit financing in the case of the PA. The PA does not have authority to issue currency and has virtually no control over taxes (the PA does have the power to charge various user fees). Therefore, a dependence on deficit financing can be destabilizing when external sources of funding dry up or are threatened. Almost 50 percent of the PA spending was in the form of wages and salaries in 2006 . When accounting for other operational and income transfers that percentage increases to more than 80 percent of total public expenditure. The PA used its budget to finance a bureaucracy that has been used as a lucrative source of employment for hundreds of thousands of Palestinians. This could have an adverse impact on private sector growth and development as wages for those employed by the PA are substantially higher than for those employed in the private sector. Between 2000 and 2006 the average daily wage in the Palestinian public sector increased by 35 percent while the average wage in the private sector increased by only 3 percent.

Using the PA as a source of employment can be problematic. It can create dependence on the public sector and enforces a sense of entitlement by the population. It can facilitate corruption and spread nepotism and other forms of public office abuse which has become increasingly evident in the WBGS. Above all, it creates a structure of vested interests where reforms of the public sector can be resisted or could trigger political instability. Finally, inflated wages in the public sector can increase wages in the private sector during periods of recovery that, in turn, can discourage employment and growth in that sector.

Thus there are two major fiscal weaknesses in the PA that need to be addressed. First, dependence on foreign aid must be diminished and tax transfers from Israel increased and, second, the use of the PA as an employer of last resort must be stopped. These two elements can be destabilizing if and when the political climate changes, as happened in 2000 and 2006 when public revenues were held hostage for political reasons by Israel and foreign donors. Any future peace arrangement with the PA should include steps toward weaning the PA off foreign aid and endowing it with more fiscal powers to collect and impose its own taxes. Such steps, if taken, could enhance the legitimacy of the PA among the population and increase its financial independence from capricious international relations. Furthermore, employment in the
Palestinian public sector should be based on real economic needs, not on political considerations such as soaking up the labor surplus and buying loyalties. Although absorbing labor surplus in times of economic crises is practiced by many countries, it remains unsustainable in the long run and might inhibit growth in the private sector and endanger political cohesion and reduce efficiency if jobs are based on political loyalty rather than skills and abilities.

Trade and financial sanctions

After the Oslo Accords, the Palestinian economy under the PA was subjected to several waves of debilitating financial, trade, and other economic sanctions. Since 1997 successive Israeli governments have used the taxes collected on behalf of the Palestinians in

punitive ways during periods of heightened hostilities. ${ }^{21}$ These sanctions were imposed on-and-off depending on the state of the political tensions between Palestinians and Israelis. But comprehensive financial sanctions were not imposed until after Hamas won the elections in January 2006. Following that, in March 2006 Western powers and Israel banned direct aid to the PA, causing it to be unable to meet its payroll, let alone tending to other public expenditures. ${ }^{22}$

According to the Palestinian-Israeli agreements, Israel collects various taxes on
Table 2: Palestinian Authority fiscal budgets, 1998-2006 (millions of Israeli Shekels and millions of US\$)

$$
\begin{array}{lll}
\text { Total } & \text { Totalpublic } & \text { Annual } \\
\text { revenues } & \text { expenditure } & \text { deficit }
\end{array}
$$

1998 IS $3,221 \quad$ IS $6,574 \quad$ IS 3,353

$\$ 884.9 \quad \$ 1,806.0 \quad \$ 921.1$

1999 IS 3,615 IS $6,918 \quad$ IS 3,303

$\$ 903.8 \quad \$ 1729.5 \quad \$ 825.8$

2000 IS $4,068 \quad$ IS $5,848 \quad$ IS 1,780

$\$ 959.4 \quad \$ 1379.2 \quad \$ 419.8$

IS 4,633

$\$ 1,097.8$

IS 5,718

$\$ 1,270.6$

IS 3,735

$\$ 747$

IS 4,174

IS 5,052

$\$ 1,161.3$

IS 5,174

$\$ 1,149.7$

Source: Palestinian Finance Ministry. US\$ Palestinian Ministry of Finance for that year. The

IS $/ \$$ rate was $(3.63,4.00,4.24,4.22,4.50,5.00$,

$4.70,4.35,4.50)$ for 1998-2006, respectively. The

Palestinian budget is prepared in Israeli Shekels. conversion employs the exchange rate used by the 
behalf of the Palestinians, such as import and export duties, value-added taxes, labor taxes, and other excise taxes such as cigarette and gasoline taxes. Israel then transfers the tax monies to the Palestinian Treasury monthly. The amount constitutes a considerable portion of Palestinian public receipts. In 2006, for example, the tax fund was estimated to account for approximately 60 percent of Palestinian revenues. ${ }^{23}$ Foreign aid is another vital item and essential to Palestinian fiscal well-being. Foreign donors supply approximately 40 to 50 percent of Palestinian revenues (the United States, the European Union, Japan, and Arab countries are the major donors). ${ }^{24}$ The sanctions regime has been disastrous to Palestinians and only intensified poverty and political instability. The PA has not been able to meet its payroll obligations for almost two years now and PA workers were only able to receive partial back payments.

The impact of these financial sanctions goes beyond interruption of income flows. Under threat of sanctions by the United States and Israel, local banks in Gaza were not permitted to conduct any financial transactions with the Hamas-led government. ${ }^{25}$ This action has reduced the supply of Israeli Shekels in the territories and affected the ability of overseas Palestinians to send in remittances. ${ }^{26}$ This resulted in the Palestinian government resorting to smuggling cash in suitcases from abroad. Disgruntled workers and military personnel have repeatedly staged violent protests on the streets of the WBGS demanding back-pay. ${ }^{27}$ On several occasions, Palestinian security forces disrupted the meetings of the Palestinian Legislative Council to protest lack of payment. Because more than 40 percent of the Gazan workforce is employed by the PA, financial sanctions directly threaten half of the population in Gaza and their families who are dependent on those working for the PA.

The financial sanctions are compounded by trade sanctions. Israel has suspended trade and closed its boarder crossing with Gaza. Supplies are reduced to a bare minimum and are permitted on humanitarian grounds only. The economic sanctions are so severe that the health situation has reached a humanitarian crisis in Gaza. ${ }^{28}$

On 20 September 2007, the Israeli government declared Gaza a "hostile entity" and severed all trade relations with it. ${ }^{29}$ Trade restrictions with Gaza and the West Bank have been in place since Israel imposed its closure policy in 1993 and even before, since 1967. All agricultural and other exports from WBGS have to pass through Israel, and the restrictions on trade with Gaza have meant millions of dollars in losses to Palestinian farmers and businesses. Since the beginning of the Oslo peace process, the European Union encouraged Gaza farmers to produce cash or export crops like flowers and strawberries for sale in Israel and the European markets. According to the Palestinian Bureau of Central Statistics, around 16 percent of Gaza's workforce (40,000 farmers) is employed in agriculture. The trade sanctions with Gaza have been devastating to the agricultural sector that already reeled from lack of access to sufficient water supplies and regular markets. ${ }^{30}$

The trade sanctions are punitive to the entire Palestinian population and economy. An examination of WBGS trade patterns helps to exemplify the damage Israel trade sanctions cause. According to the United Nation Conference on Trade and Development (UNCTAD), Palestinian exports to Israel and the rest of the world declined to about 5 percent of GDP by 2006, as compared to 12 percent in 1972 . Moreover, Palestinians have become increasingly dependent on Israel to meet domestic demand for goods and services. PA trade with Israel constitutes approximately 66 percent of PA total trade, while Israel's trade with the PA is only 3 percent of total Israeli trade. ${ }^{31}$ As of 2006 , imports as a percentage of Palestinian GDP reached 86 percent, while 43 percent of Palestinian private consumption comes from one source: Israel. Therefore, any interruption of trade between Israel and WBGS can have a disproportionately large impact on Palestinians. This asymmetric trade pattern provides Israel with incentives and leverage to maintain sanctions because any losses to the Israeli economy would be minimal.

Trade with Israel has implications for the level of Palestinian economic development and standard of living as sanctions distort work and investment incentives. It is unclear how long it would take the economy to recover to pre-sanctions levels if the sanctions were removed. It is ironic that the sanctions create misery, poverty, and unnecessary hardship while their implementation has not achieved the objectives Israel intended.

\section{Conclusion}

A fragile Palestinian entity is costly, imperils regional peace, and forms an obstacle to finding a viable, stable solution to the Palestinian-Israeli conflict. A fragile peace likely means continued costly interventions by the United States and European nations. The peace process did not bear fruits in the battered Palestinian territories that have been experiencing socio-economic decline since the Oslo Accords. The lack of economic progress and the failed peace process are intertwined. Various political decisions led to a process of de-development in the WBGS which, in turn, led to a fragile PA that was to be the guardian and enforcer of the peace process. The impact of economic sanctions and closures would have been less severe had the PA been less dependent on trade with Israel and public revenues primarily accumulated from donor assistance. The lessons learned from the past 15 years of an ineffective peace process should be incorporated in any future peace arrangements. That includes overhauling trade and fiscal structures in the Palestinian government and granting Palestinians proper political and economic powers to manage their own affairs. Without such powers, any future PA will remain fragile and risks eventually collapse.

Notes

Basel Saleh is assistant professor of economics and a member of the peace studies faculty at Radford University, Radford, VA, U.S.A. He may be reached at bsaleh@radford.edu. 
1. Hamas is the Arabic acronym for the Islamic Resistance Movement, Haraket al-Moquawamah al-Islamiah.

2. See Pearlman (2007).

3. For information on Palestinian corruption see, e.g., PHRMG (2004).

4. Brynen (2000, p. 3). A similar figure is cited in Ehrenfeld (2002, p. 5). EUFunding.org.uk $(2004$, p. 3) put the total amount received directly and indirectly by the PA at over $\$ 10$ billion from 1993-2006. During the same time period, Israel received $\$ 28$ billion dollars from the United States in military and economic aid.

5. See "60 Minutes." CBS News. The transcript of this report is available at http://www.cbsnews.com/stories/2003/11/07/60minutes/main582487.shtml [accessed 1 June 2008].

6. Gazit (1995, pp. 213-235).

7. Gazit (1995, p. 2, pp. 230-231).

8. The reduction in work hours was the direct result of local strikes that the Palestinian Unified Leadership enforced, Israeli curfews, mourning days for Palestinians killed by Israel, and protest days.

9. UNESCO (1993). Also see, United Nations Report of the Economic and Social Council, 14 May 1993 (p. 10). General Assembly, Economic and Social Council Substantive Session of 1993. Available on the website of the United Nations Information System on the Question of Palestine (UNISPAL) http://domino.un.org/unispal.nsf.

10. The first Palestinian elections were held 20 January 1996. For details and discussion of the first elections, see Shikaki (1996) and Lamis (1996). Also see the website of the Central Elections Commission - Palestine at http://www.elections.ps where one may find detailed statistics on the first and second elections and the political program for each party that participated in the elections.

11. Hamas' official candidates list is called the Movement for Change and Reform. Four other candidates also won but are Hamas-supported, raising the number of seats that Hamas controls to 78 (59 percent). See Saad (2006).
12. This resembles the events in Algeria after the 1992 elections when the army intervened and a civil war ensued. Algeria is still trying to overcome that civil war in which over 100,000 Algerians died. For example, in September 2007, two suicide bombers killed over 50 people. See http://news.bbc.co.uk/2/hi/africa/6985672.stm [accessed 7 November 2007]. Also see Martinez (2000).

13. The Palestinian Center for Human Rights in Gaza reported that 190 Palestinian were killed and at least 700 injured between 7 and 14 June 2007. See "Black Pages in the Absence of Justice: A Report on the Bloody Fighting in the Gaza Strip from 7 to 14 June 2007." http://www.pchrgaza.org/files/Reports/English/pdf_spec/ Gaza\%20Conflict\%20-\%20Eng\%209\%20october..pdf [accessed 1 June 2008].

14. See Roy (2002) and Hass (2002) for a review of the historical background of the closure and its impact on Palestinians.

15. The United Nations Office for the Coordination of Humanitarian Affairs (OCHA) publishes annual figures on the number of Israeli manned and unmanned roadblocks in the West Bank and other statistics on movement restrictions. As of October 2007 , there were 563 such roadblocks in the West Bank. See Report No. 50, http://www.ochaopt.org/documents/OCHA_AccessAndMovement_No50.pdf [accessed 1 June 2008].

16. See, e.g., Simpson (2007).

17. The sample correlation coefficient between the two variables is -0.90 .

18. The data for this section was made available by the Palestinian Ministry of Finance. I am thankful for its assistance.

19. World Bank (1999, p. 4).

20. World Bank (1999, p. 88); BBC News http://news.bbc.co.uk/2/hi/middle_east/ 4969212.stm [accessed 20 November 2007].

21. The first to use this method was Israeli prime minister Benjamin Netanyahu in 1997. Also, prime minister Ariel Sharon withheld taxes for two years after the al Alqsa intifada. Today, Israel still withholds over $\$ 700$ million of tax money owed to the Palestinians.

22. Haaretz. "Officials: Israel Ready to Transfer withheld Tax Revenues to PA." 3 June 2007. http://www.haaretz.com/hasen/spages/865554.html [accessed 20 November 2007]. 
23. This figure is based on data obtained from the Palestinian Ministry of Finance. In 2006 , Israeli tax collections on behalf of the Palestinians were about $\$ 803$ million, or an average of $\$ 66$ million a month.

24. According to the USAID "Greenbook" (USAID, n/a), the United States has given the Palestinian economy $\$ 348$ million in 2005.

25. Israel indirectly controls the banking system in the Palestinian territories. All banks in the WBGS have ties with Israeli counterparts to move money in and out of the WBGS

26. Haaretz. "Gaza Banks May Shut Down by January Over Financial Clamp Down." 4 October 2007. http://www.haaretz.com/hasen/spages/909518.html [accessed 1 June 2008].

27. The New York Times. "Palestinians Mount Violent Protest over Lack of Paychecks.” 15 June 2006.

28. On 2 May 2008, the Israeli paper Haaretz revealed that Gaza sewage is being pumped directly to the Mediterranean Sea without proper treatment because of lack of fuel supplies and chemicals needed for the treatment process. This might have disastrous environmental consequences for Palestinians, Israelis, and other. See "Gaza Sewage Pumped into the Sea Over Past Three Months." 4 May 2008. http://www.haaretz.com/hasen/spages/980091.html [accessed 1 June 2008].

29. Haaretz. "Cabinet Declares Gaza a 'Hostile Entity'." 20 September 2007. http://www.haaretz.com/hasen/spages/905561.html [accessed 1 June 2008].

30. For an article on the impact of trade sanctions on Gaza farmers, see Haaretz, "Israel Okays Renewal of Flower, Strawberry Exports from Gaza." 22 November 2007. http://www.haaretz.com/hasen/spages/926607.html [accessed 1 June 2008].

\section{UNCTAD (2007).}

\section{References}

Brynen, R. 2000. A Very Political Economy: Peace Building an Foreign Aid in the West Bank and Gaza. Washington, D.C.: United States Institute of Peace Press.

Collier, P., et al. 2003. Breaking the Conflict Trap: Civil War and Development Policy. Washington, D.C.: The World Bank and Oxford University Press.

Chauvet, L. and P. Collier. 2005. "Development Effectiveness in Fragile States: Spillovers and Turnarounds." Working Paper. http://www.oecd.org/dataoecd/32/59/34255628.pdf. [accessed 2 November 2007]. Ehrenfeld, R. 2002. "Where Does the Money Go? A Study of the Palestinian Authority." B'nai B'rith. http://www.public-integrity.org [accessed 9 February 2008].

EUFunding.org.uk. 2004. "Managing European Tax Money: Supporting the Palestinian Arabs: A Study in Transparency." August. http://eufunding.org.uk/FPC2004Report.pdf [accessed 3 June 2008].

Gazit, S. 1995. "The Carrot and the Stick: Israel's Policy in Judea and Samaria, 1967-1968." Washington, D.C.: B'nai B'rith.

Hass, A. 2002. "Israel's Closure Policy: An Ineffective Strategy of Containment and Repression.” Journal of Palestine Studies, Vol. 31, No. 3, pp. 5-20.

Lamis, A. 1996. "The Palestinian Elections: Moving towards Democracy or One Party Rule.” Journal of Palestine Studies, Vol. 25, No.3 , pp. 5-16.

Lipset, S. 1959. "Some Social Requisites of Democracy: Economic Development and Political Legitimacy." American Political Science Review, Vol. 53, No. 1, pp. 69-105.

Martinez, L. 2000. The Algerian Civil War: 1990-1998. New York: Columbia University Press.

Nafziger, W. and J. Auvinen. 2003. Economic Development, Inequality, and War: Humanitarian Emergencies in Developing Countries. New York: Palgrave Macmillan.

Pearlman, W. 2007. "Fragmentation and Violence: Internal Influences on Tactics in the Case of the Palestinian National Movement, 1918-2006." Unpublished PhD dissertation. Harvard University.

[PHRMG] Palestinian Human Rights Monitoring Group. 2004. "The Chaos of the Corruption: Challenges for the Improvement of the Palestinian Society." October http://www.phrmg.org/Corruption\%20in\%20the\% 20Palestinian\%20Authority. htm [accessed 1 June 2008].

Preble, C. and J. Logan. 2006. “Are Failed States a Threat to America?” Reason, Vol. 38, No. 3, pp. 32-38.

Roy, S. 2002. "Ending the Palestinian Economy." Middle East Policy, Vol. 9, No. 2, pp. 122-165.

Saad, W. 2006. "The Siege: A Study on the Siege of the Palestinian People and Attempts to Overthrow the Government of Hamas." (In Arabic). Beirut: Al Zaytouna Center for Studies and Consultations. [The book is in Arabic and can be accessed on http://www.alzaytouna.net/arabic/?c=137\&a=21524]

Shikaki, K. 1996. "The Palestinian Elections: An Assessment." Journal of Palestine Studies, Vol. 25, No. 3, pp. 17-22.

Simpson, Cam. 2007. "In West Bank, Checkpoints Splinter Palestinian Economy." The Wall Street Journal. 20 November 2007. http://online.wsj.com/article/ SB 1 19549435612298089.html [accessed 2 June 2008].

Sung, H. 2004. "State Failure, Economic Failure, and Predatory Organized Crime: A 
Comparative Analysis." Journal of Research in Crime and Delinquency, Vol. 41, No. 2, pp. 111-129.

[UNCTAD] United Nations Conference on Trade and Development. 2007. Report on UNCATD Assistance to the Palestinian People, 11 July 2007. http://www.unctad.org/en/docs/tdb54d3_en.pdf [accessed 15 February 2008].

[UNESCO] United Nations Educational, Scientific, and Cultural Organization. 1993. United Nations Seminar on Assistance to the Palestinian People Report. April. Paris: UNESCO.

[USAID] United States Agency for International Development. 2005. "Fragile States Strategy." http://www.usaid.gov/policy/2005_fragile_states_strategy.pdf[accessed 1 June 2008].

[USAID] United States Agency for International Development. n/a. "U.S. Overseas Loands and Grants" website (The "Greenbook."): http://qesdb.usaid.gov/gbk/.

World Bank. 1999. "Aid Effectiveness in the West Bank and Gaza." The Secretariat of the Ad Hoc Liaison Committee. 19 December 1999. Washington, D.C.: The W orld Bank. http://www-wds.worldbank.org/external/default/WDSContentServer/ WDSP/IB/2008/03/26/000334955_20080326113811/Rendered/PDF/430640W P01NO0P10Effectiveness0front.pdf [accessed 2 June 2008]. 